\title{
State of Organic Matter and Particularities of Physicochemical Properties of Soils in the Endogenous Hydrogen Seepage Zones
}

\author{
Natalia Ivanovna Sukhanova, Tatiana Aleksandrovna Zubkova \\ Faculty of Soil Science, Lomonosov Moscow State University, Moscow, Russia \\ Email: vogudin@yandex.ru,dusy.taz@mail.ru
}

How to cite this paper: Sukhanova, N.I. and Zubkova, T.A. (2018) State of Organic Matter and Particularities of Physicochemical Properties of Soils in the Endogenous Hydrogen Seepage Zones. Open Journal of Soil Science, 8, 186-196.

https://doi.org/10.4236/ojss.2018.88015

Received: May 16, 2018

Accepted: August 20, 2018

Published: August 23, 2018

Copyright ( $\odot 2018$ by authors and Scientific Research Publishing Inc. This work is licensed under the Creative Commons Attribution International License (CC BY 4.0).

http://creativecommons.org/licenses/by/4.0/

\begin{abstract}
In the territory of the Voronezh region of Russia in ordinary middle loam chernozem the elevated concentration of endogenous hydrogen streams up to $0.65 \%$ at the depth of $100-120 \mathrm{~cm}$ was detected. This phenomenon is observed in the center of depressions. The soils differ in morphological, chemical and physical properties. The top humus horizon is markedly bleached comparing to the soil outside the depression: The lightness $\mathrm{L}$ readings increase for $16 \%-30 \%$. The soil acidity (up to $\mathrm{pH} 4.5-5.0$ ) and organic carbon content are elevated comparing to the sample for reference. The proportion of fulvic acids increases on average thrice as compared with the soils outside the hydrogen fluids influence zone. Despite the high humus content the mechanical strength of aggregates decreases 3 - 4 times. Under conditions of hydrogen fluids, changes occur at the aggregate structural level in the direction of decreasing their mechanical strength. In the center of the depressions strength of aggregates is reduced by 2 - 3 times in comparison with the control. The opposite regularity was observed in the absence of hydrogen flows, where the strength of aggregates was 3 times higher than in comparison with the control.
\end{abstract}

\section{Keywords}

Soil, Humus, Hydrogen, Aggregate Structure, Mechanical Strength of Aggregates, Matrix Organization of Soil

\section{Introduction}

In the European territory of Russia there are soils of the lows which in morphological measures and chemical properties are different from ordinary zonal soil 
in depression landforms. They are confined to deep faults with Earth outgassing and hydrogen fluids cropping out. This process is dynamic, not steady in time and space; it conforms to global ground cycles [1] [2]. The hydrogen streams in the underground air can reach $3000-5000$ ppm which is much higher than their concentration in soils outside the influence of endogenous hydrogen streams. In places of intense hydrogen seepage depressions of different size appear, they are easy to see at the space images. They are regularly rounded and have unusual soil properties [2]. These locations occur at almost all continents. Comparable sinkhole groups were found in Germany, USA, Canada, Argentina, Brazil, Poland, Belarus, Ukraine, Kazakhstan, Australia and Africa. In Russia the sinkholes confined to the zones of elevated hydrogen release are mostly found in Voronezh, Lipetsk, Volgograd and Moscow regions, in the north of West Siberia [3] and they cover big territories. The hydrogen sinkholes density can be 15 up to $50 \%$ and more [1] [2]. If the hydrogen seepage places are confined to a forest geobiocoenosis forest fire can start. For example, the forest fire frequency in Transbaikal is colligated with hydrogen Earth outgassing [4]. Another pressing problem is the question of agricultural soil under the conditions of endogenous hydrogen influence. According to local agronomists the cereal crop on the chernozem can go down by $30 \%$ - 40\%. In hydrogen fluids zones the soil formation conditions change fundamentally due to $\mathrm{H}_{2}$ influence over oxidation-reduction modes, humus formation, microbiological processes [3] [5] [6]. However there is only incomplete data on this subject in the literature. The state of the soil aggregate structure in places of hydrogen degassing has not been studied, although aggregates play an important ecological role in soil functioning [7].

The research paper objective is to estimate the particularities of the organic matter, physicochemical properties and the aggregate structure of the soil in the places of endogenous hydrogen seepage.

\section{Research Subject}

The experimental lots have been assigned in the North East part of Voronezh region of Russia (districts of Novokhopersk, Povorino, Borisoglebsk) with the general area of $3600 \mathrm{~km}^{2}$ near the river Hoper elbow of capture. There is ordinary chernozem and the soil is heavily used in agriculture. The studied depressions (more than twenty) showed significant concentration of hydrogen at the depth of $120 \mathrm{~cm}$, to the period of research it was at average $0.65 \%$ (volume percentage) which is much higher than usual concentration in the soil air. There is temporary or permanent overwetting in these depressions. The soil is affected by two factors-air flow and overwetting. Previously it was shown that the temporary overwetting processes impact the morphological and chemical properties of the soil [8] [9] [10] [11].

The experimental lots are two regularly rounded depressions. The depression I ( $5 \mathrm{~km}$ to the east of the village Okryabrekoy Povorinsky district, $51^{\circ} 13^{\prime} 49^{\prime \prime} \mathrm{N}$, $\left.42^{\circ} 02^{\prime} 24^{\prime \prime E}\right), 0.6 \mathrm{~m}$ deep, about $100 \mathrm{~m}$ in diameter, has been suspended from 
agricultural usage for 15 years. The depression II, about $0.4 \mathrm{~m}$ deep, about $20 \mathrm{~m}$ in diameter is located on the regular arable land ( $8 \mathrm{~km}$ to the south-west from the village of Okryabrkoe Povorinsky district, $\left.51^{\circ} 10^{\prime} 43^{\prime \prime N}, 41^{\circ} 55^{\prime} 20^{\prime \prime} \mathrm{E}\right)$. In the soil of the depression II the hydromorphism marks are hardly in evidence, it's not different from ordinary chernozem outside the depression in its morphological characteristics.

The climate in the Povorinsky area is moderately continental with hot and dry summers and moderately cold winters with a stable snow cover and well-marked transitional seasons. The annual amount of precipitation in the territory of the district is from 450 and more than $500 \mathrm{~mm}$. Territory refers to the zone of insufficient moisture, which is due to high volatility in the warm period. The average annual air temperature is $+5.6^{\circ} \mathrm{C}$. The average of the absolute maximum temperatures are $+36^{\circ} \mathrm{C}$, the average of the absolute minimum temperatures are $-31^{\circ} \mathrm{C}$.

The soils of the region are represented by chernozems typical and common.

Soil samples were taken September 20 - September 29 in different elements of the depressions (center, border and outside of depression) at the depths indicated in Table 1 and Table 2.

\section{Research Methods}

The molecular hydrogen stream was measured on the field with the portable hydrogen gas analyzer BG-3B (Russia) [3]. The humus content was estimated using Tyurin Method [12]. The acidity was measured potentiometricly with a ion-indicating electrode. To find out the make up of humus the pyrophosphate method of humus composition analysis by Kononova and Belchikova was applied [13]. The method allows to estimate the most transformable part of the humus which includes free forms and forms bound with non-silicate iron and aluminium, and also calcium [13] [14]. That is the faction of the soil organic matter that will first react at hydrothermal conditions changing.

The state of aggregates was measured by mechanical strenth $(\mathrm{P})$. This attribute reflects the soil physical properties (granulometric texture, specific surface area, porosity) as well as surface chemical properties [15] [16]. The strength of aggregates of 3 - $5 \mathrm{~mm}$ was estimated by direct mechanical mashing method on the apparatus (MP-2C modified model) and expressed in newtons [15] [17]. This method allows to study air-dry aggregates with high repetition (40 and more) and without preliminary violation of their integrity. The statistical processing of results was made by "Statistica-6.0" software.

\section{Results and Discussion}

To estimate the endogenous hydrogen impact on humus and aggregates properties the soil in the center of the depressions created under the conditions of hydrogen fluids (depressions I and II) was compared with the soil outside the depressions 
Table 1. Total organic hydrogen content and $\mathrm{pH}$ for the depression soils.

\begin{tabular}{|c|c|c|c|c|c|c|c|}
\hline & Horizon, cm & $\mathrm{pH}$ & $\mathrm{C}_{\text {total, }} \%$ & & Horizon, cm & $\mathrm{pH}$ & $\mathrm{C}_{\text {total }}, \%$ \\
\hline \multicolumn{4}{|c|}{ Depression I } & \multicolumn{4}{|c|}{ Depression II } \\
\hline \multirow{8}{*}{$\begin{array}{l}\text { Depression } \\
\text { center }\end{array}$} & $\mathrm{A}(0-8)$ & 5.02 & 5.38 & \multirow{8}{*}{$\begin{array}{l}\text { Depression } \\
\text { center }\end{array}$} & $\mathrm{A}(0-24)$ & 5.37 & 2.47 \\
\hline & A $(8-33)$ & 4.61 & 3.60 & & A $(23-27)$ & 5.73 & 2.35 \\
\hline & $\mathrm{AE}(33-48)$ & 4.48 & 2.07 & & A $(24-36)$ & 5.45 & 1.82 \\
\hline & $\mathrm{E}(48-77)$ & 4.48 & 0.71 & & A $(36-46)$ & 5.12 & 1.34 \\
\hline & B1 (77 - 95) & 4.17 & 0.53 & & $\mathrm{AB}(46-60)$ & 4.98 & 1.80 \\
\hline & B2 (95 - 115) & 4.47 & 0.70 & & B1 (60 - 86) & 4.95 & 0.47 \\
\hline & B2 (115 - 135 & 4.70 & 0.42 & & B2 (86 - 97) & 4.87 & 0.39 \\
\hline & BC (135 - 155) & 5.03 & 0.30 & & C (97 - 110) & 5.03 & 0.07 \\
\hline \multirow{6}{*}{$\begin{array}{c}\text { Depression } \\
\text { boundary }\end{array}$} & $\mathrm{A}(0-4)$ & 6.16 & 4.00 & \multirow{6}{*}{$\begin{array}{c}\text { Out of } \\
\text { depression }\end{array}$} & $A(0-22)$ & 6.17 & 2.28 \\
\hline & A $(4-26)$ & 6.14 & 2.93 & & A $(22-25)$ & 6.03 & 2.14 \\
\hline & $A(26-51)$ & 6.23 & 1.84 & & A $(26-50)$ & 6.81 & 1.88 \\
\hline & $\mathrm{AB}(51-65)$ & 5.88 & 0.59 & & $\mathrm{AB}(50-70)$ & 7.21 & 1.29 \\
\hline & B1 (65 - 93) & 5.76 & 0.37 & & B1 (70 - 90) & 7.85 & 0.97 \\
\hline & B2C (93 - 115) & 5.71 & 0.49 & & $\mathrm{~B} 2_{\mathrm{Ca}}(90-116)$ & 8.04 & 0.60 \\
\hline \multirow{6}{*}{ Out of depression } & $A(0-27)$ & 6.29 & 2.37 & & $C(116-120)$ & 8.12 & 0.16 \\
\hline & A $(27-57)$ & 7.10 & 1.83 & & & & \\
\hline & $\mathrm{AB}(57-76)$ & 7.74 & 1.23 & & & & \\
\hline & B1 (76 - 93) & 7.96 & 0.76 & & & & \\
\hline & $\mathrm{B} 2_{\mathrm{Ca}}(93-110)$ & 8.07 & 0.38 & & & & \\
\hline & $\mathrm{BC}(110-120)$ & 8.10 & 0.28 & & & & \\
\hline
\end{tabular}

Note: A-humic horizon, B-illuvial horizon, E-eluvial horizon, C-parent materials.

Table 2. The content of humic and fulvic acids in soils of depressions.

\begin{tabular}{|c|c|c|c|c|c|c|c|}
\hline & Horizon, $\mathrm{cm}$ & $\begin{array}{c}\mathrm{C}_{\mathrm{ga}}, \\
\% \text { of } \mathrm{C}_{\text {total }}\end{array}$ & $\begin{array}{c}\mathrm{C}_{\mathrm{fa}} \\
\% \text { of } \mathrm{C}_{\text {total. }}\end{array}$ & & Horizon, $\mathrm{cm}$ & $\begin{array}{c}\mathrm{C}_{\mathrm{ga}} \\
\% \text { of } \mathrm{C}_{\text {total }}\end{array}$ & $\begin{array}{c}\mathrm{C}_{\mathrm{fa}}, \\
\% \text { of } \mathrm{C}_{\text {total.. }}\end{array}$ \\
\hline \multicolumn{4}{|c|}{ Depression I } & \multicolumn{4}{|c|}{ Depression II } \\
\hline \multirow{5}{*}{$\begin{array}{l}\text { Depression } \\
\text { center }\end{array}$} & $\mathrm{A}(0-8)$ & 10.2 & 30.0 & \multirow{5}{*}{$\begin{array}{l}\text { Depression } \\
\text { center }\end{array}$} & $\mathrm{A}(0-24)$ & 10.2 & 30.2 \\
\hline & A $(8-33)$ & 3.8 & 34.0 & & A $(23-27)$ & 10.4 & 25.4 \\
\hline & $\mathrm{AE}(33-48)$ & 8.2 & 32.4 & & A $(24-36)$ & 13.4 & 28.4 \\
\hline & $\mathrm{E}(48-77)$ & 10.4 & 43.2 & & A $(36-46)$ & 15.0 & 31.2 \\
\hline & B1 (77 - 95) & 8.0 & 40.5 & & $\mathrm{AB}(46-60)$ & 7.4 & 16.8 \\
\hline \multirow{4}{*}{$\begin{array}{l}\text { Depression } \\
\text { boundary }\end{array}$} & $\mathrm{A}(0-4)$ & 6.0 & 8.6 & \multirow{7}{*}{$\begin{array}{l}\text { Outside the } \\
\text { depression }\end{array}$} & B1 $(60-86)$ & 3.4 & 30.6 \\
\hline & A $(4-26)$ & 7.4 & 13.6 & & $A(0-22)$ & 10.2 & 16.2 \\
\hline & $A(26-51)$ & 9.8 & 22.8 & & A $(22-25)$ & 8.4 & 18.8 \\
\hline & $\mathrm{AB}(51-65)$ & 16.2 & 24.4 & & A $(26-50)$ & 9.6 & 17.0 \\
\hline \multirow{3}{*}{$\begin{array}{l}\text { Outside the } \\
\text { depression }\end{array}$} & $\mathrm{A}(0-27)$ & 8.4 & 10.2 & & $\mathrm{AB}(50-70)$ & 7.4 & 17.4 \\
\hline & A $(27-57)$ & 9.2 & 14.8 & & & & \\
\hline & $\mathrm{AB}(57-76)$ & 8.6 & 12.6 & & & & \\
\hline
\end{tabular}

Note: A-humic horizon, B-illuvial horizon. 
where there were no elevated molecular hydrogen streams (control area). Apart from that the soil properties (depressions I and II) were compared with similar ordinary chernozem in the depressions in Rostov region [18] [19], with no endogenous hydrogen outgassing [17].

Morphological properties. Spectral reflectivity of soils reflects the composition and properties of soil organic matter [14]. In the center of the depressions I and II The top humus horizon is noticeably bleached comparing to the soil outside the depression. The lightness L readings according to International color system increase for $16 \%$ - 30\% depending on the degree of the depression development (Table 3).

In two depressions the soil profile is totally washed from carbonates regardless of the overwetting degree. In the big depression I there has been observed noticeable humus mobility (cutans presence) on the structural separates borderlines. In the small depression II the cutans are feebly marked.

Chemical properties. Regardless of the overwetting the soil of all the depressions show very low $\mathrm{pH}$ readings especially in the lower part of the profile (Table 1).

The soil of the central part of the depressions I and II is marked by very low $\mathrm{pH}$ value comparing with the soil outside the depressions: $\mathrm{pH} 4.5$ - 5.0 in the humus horizon of the bottom of the depression I and $\mathrm{pH} 6.3-7.1$ in the control area; pH 5.3 - 5.7 in the depression II and pH 6.0 - 6.8 in the soil outside it.

In the soil carbon under the conditions of molecular hydrogen streams the soils differ with elevated content of it comparing with the soil outside the depressions. Plus the difference depends on the depression size: in the center of the depression I the organic carbon content is $3.6 \%-5.4 \%$ and in the control sample it is $1.8 \%-2.4 \%$; in the depression II the organic carbon content is $2.3 \%-2.5 \%$ and in the control sample it is $2.1 \%-2.3 \%$.

According to the data of pyrophosphate-alkaline extract the fulvic acids content is much higher than humic acids content in the studied soils (Table 2).

Table 3. The color index of the humus horizon in the elements of the depressions in Voronezh region.

\begin{tabular}{lc}
\hline \multicolumn{2}{c}{ depression I } \\
\hline $\begin{array}{l}\text { depression element } \\
\text { depression center }\end{array}$ & $42.7 \pm 0.19$ \\
depression border & $35.91 \pm 0.17$ \\
Outside the depression & $32.42 \pm 0.18$ \\
$\quad$ depression II & \\
Outside the depression & $35.33 \pm 0.12$ \\
\hline
\end{tabular}


In the setting of elevated hydrogen streams the soil fulvic acids proportion relating to humic acids fraction increases by a factor of three on average in the upper horizons, along with this in the big depression I in the plough horizon the difference rises up to factor of eight. By comparison, in ordinary chernozem with the absence of $\mathrm{H}_{2}$ streams (outside the depressions) the ratio of humic acids to fulvic acids is close to 1 and it is 0.6 - 0.9 in the upper horizons depending on the depression size.

Aggregates strength properties. For the ordinary chernozem in Voronezh region with endogenous hydrogen streams detected there is the following tendency in depression landforms: in the row from the depression center towards the periphery the mechanical strength of aggregates grows (Figure 1). It appears in the big depression (Figure 1(a)) as well as in the small one (Figure 1(b)).

However under the conditions of absence of endogenous hydrogen emissions in the depressions formed only by water, on the ordinary chernozems of Rostov region [17], there were contrary regularities: on going from the center towards the periphery the mechanical strenth of aggregates falls. At the Figure 2 there is statistics of spreading of the mechanical strength of aggregates in ordinary chernozem in Rostov region in the row from the depression center towards the periphery (soil pits: 1.1, 1.2, 1.3, 1.4, 1.5).

At the separate diagrams there are results for the two upper horizons: $0-27$ $\mathrm{cm}$ and $27-50 \mathrm{~cm}$. Their strength decreasing with distance from the center of mochar was detected: in the center $\mathrm{P}$ was on average $0.28 \mathrm{~N}$, at the depression periphery- $0.1-0.15 \mathrm{~N}$. At the depth of $26-40 \mathrm{~cm}$ this dependence was more noticeable. The data variation is bigger in the upper horizons comparing with the lower horizons.

In summary, under the conditions of molecular hydrogen streams in the soil there are changes taking places at the aggregate structure level in terms of mechanical strenth of aggregates decreasing. The similar hydrogen influence was noticed in the calcareous rocks-their demolition runs more intensively [20].

Aggregates formation takes place with direct involvement of soil organic matter so the aggregates properties intersect with the total amount and quality of soil humus [15] [16]. This is the proportional connection between the aggregates strenth and the humus content that was found in the soils formed in absence of hydrogen fluids (Figure $3(\mathrm{~b})$ ). However in the territory with elevated endogenous hydrogen seepage the contrary connection between the aggregates strenth and the humus content was found (Figure 3(a)).

Consequently in the absence of hydrogen fluids there is the proportional connection between the aggregates strength and the humus content (Figure 3(b)) with a certain part of variation of data $\left(\mathrm{R}^{2}=0.47-0.48\right)$. Involving the endogenous factor (gaseous fluids with the predominant molecular hydrogen stream) the picture changes to the contrary: in the row from the sinkhole center towards the periphery the humus content decreases and the aggregates strenth increases (Figure 3(a)). The high correlation and the low variation of data $\left(\mathrm{R}^{2}=0.80-\right.$ 0.98 ) count in favor of a big impact overcovering the variation of data, caused by 
natural factors. There is a strong possibility that endogenous hydrogen streams can be this factor. It's necessary to pay attention to the fact that under the conditions of
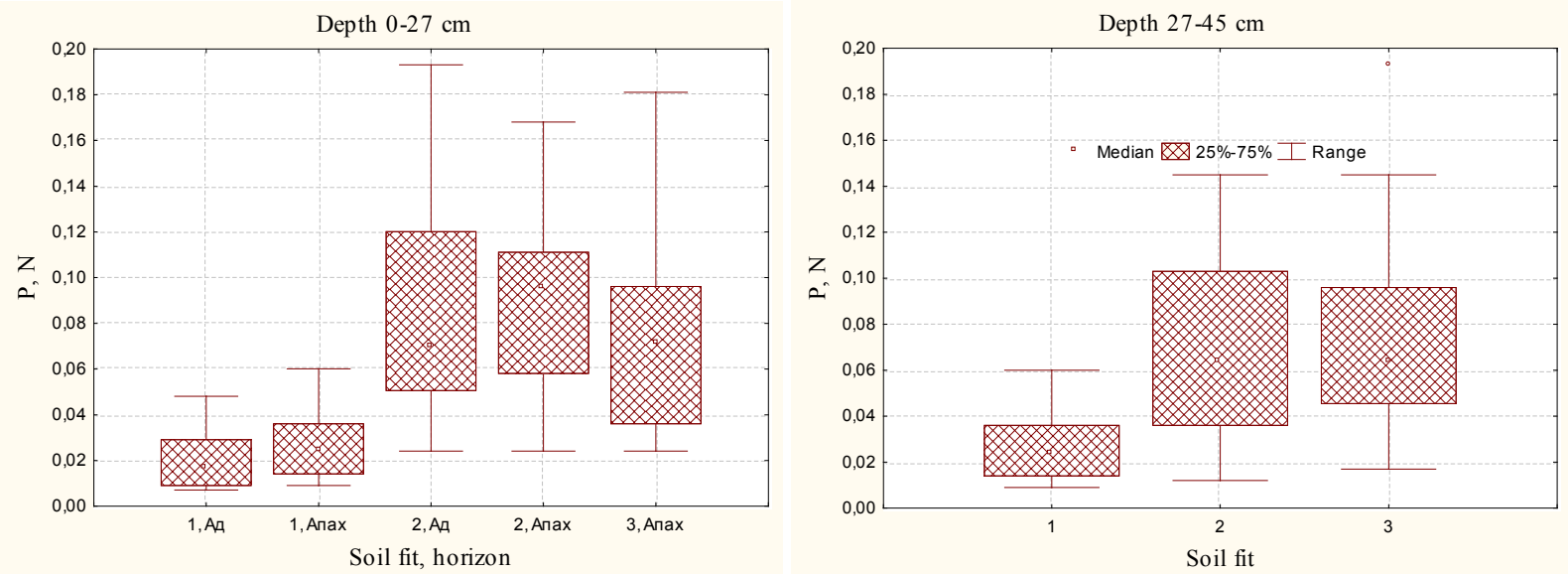

(a)
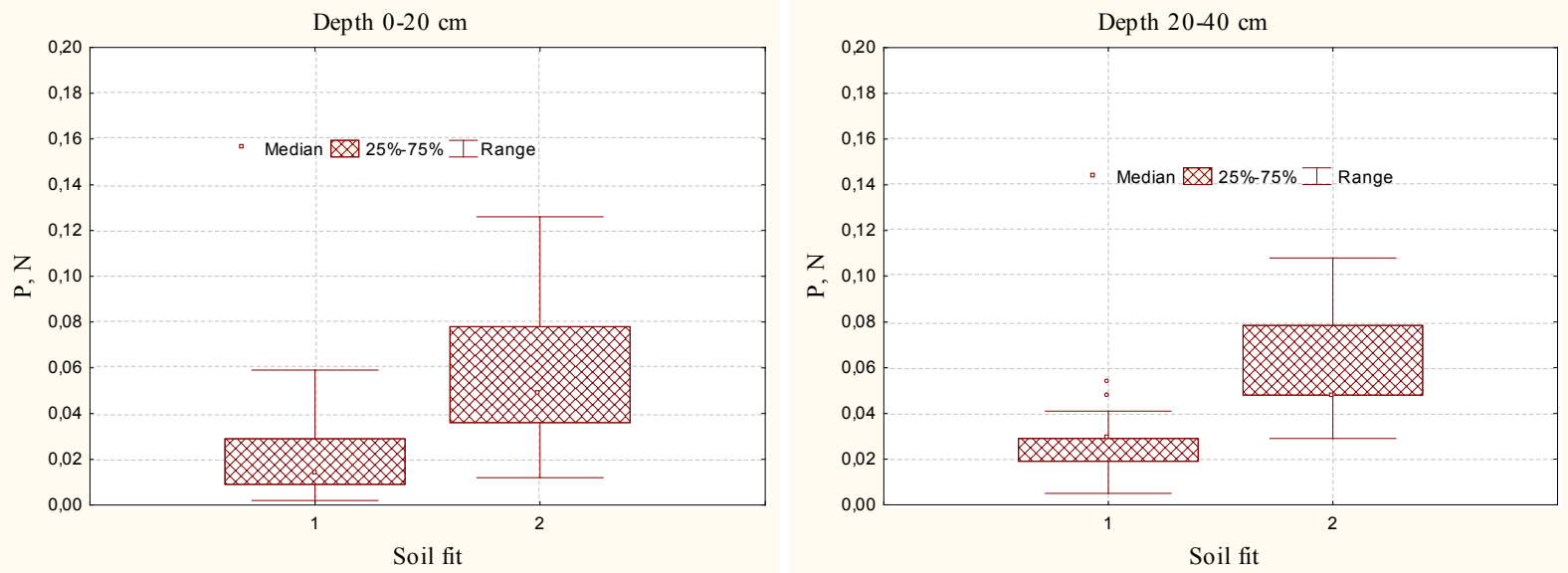

(b)

Figure 1. Statistics of aggregates mechanical strength from the upper horizons of ordinary middle loam chernozem in Voronezh region, depression I (a) and depression II (b).
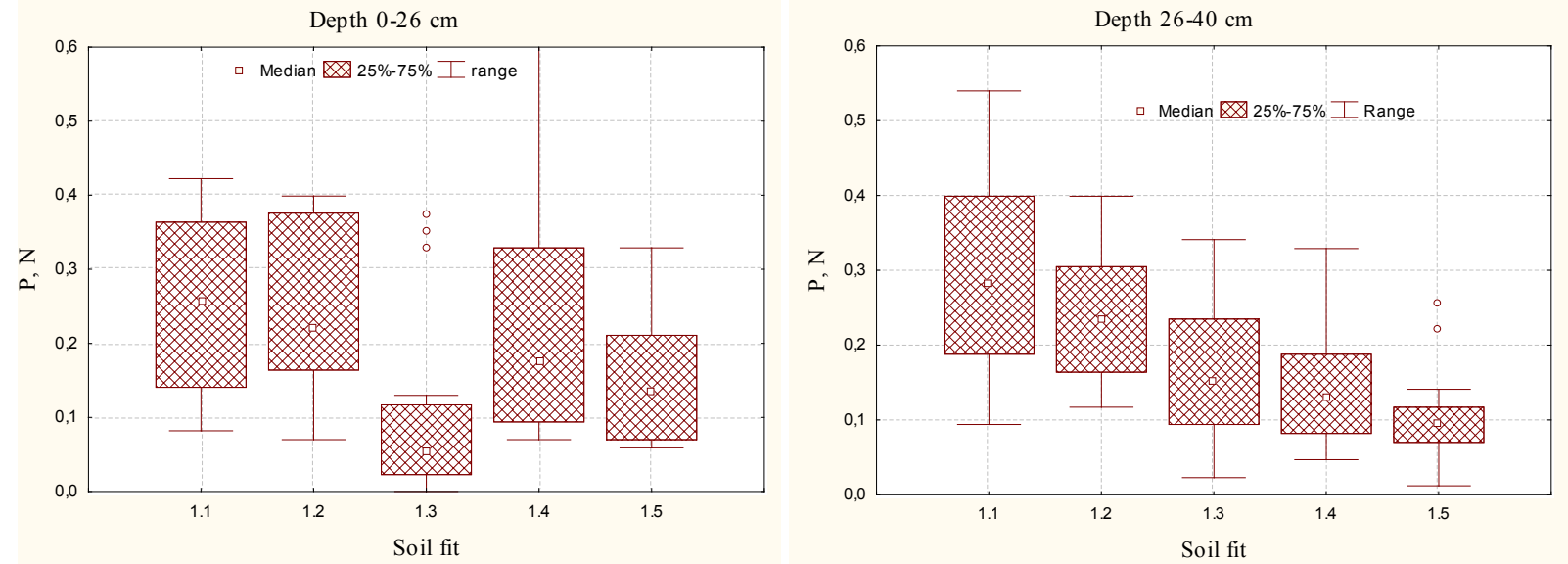

Figure 2. Statistics of the mechanical strength of aggregates in ordinary heavy loam chernozem in Rostov region. 


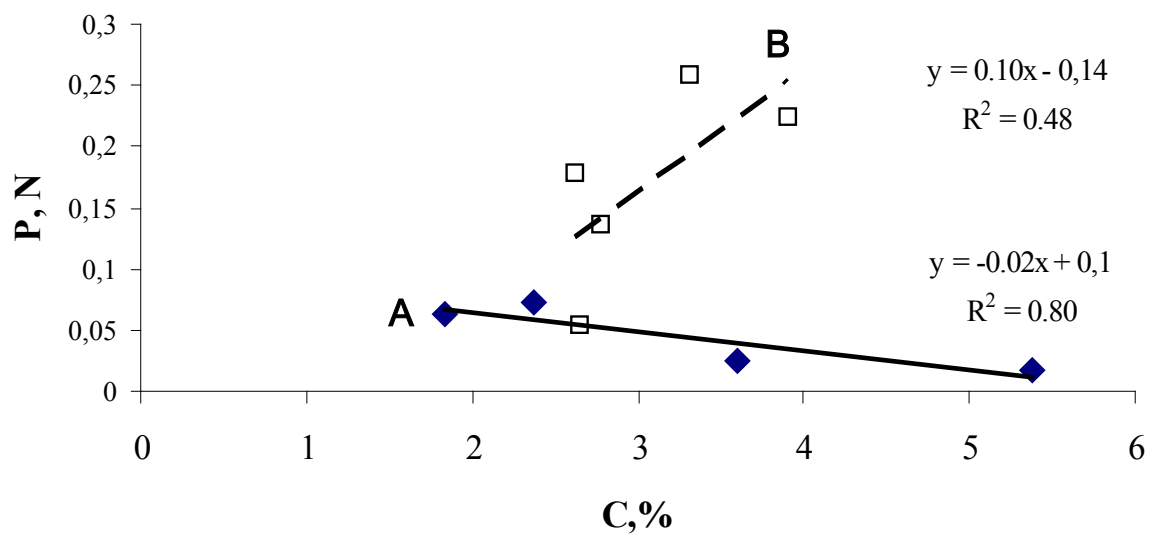

Figure 3. Dependence of aggregates mechanical strength on the humus content in the depression soils with the $\mathrm{H} 2$ streams (A) and without $\mathrm{H} 2$ (B).

hydrogen fluids streams in the depressions the humus content grows. However the aggregates strenth was decreasing though, as known, humus is one of the soil structure-forming components. And aggregates strengthening would be more expectable. Apparently under the conditions of hydrogen fluids stream the humus qualitative change such as increasing of organic matter (fulvic acids) mobile fraction and decreasing of humic acids proportion leads to the reduction of aggregates mechanical strenth.

\section{Conclusions}

The ordinary chernozem in the depressions appeared under the conditions of endogenous hydrogen seepage differs markedly from similar ordinary chernozem formed without hydrogen fluid seepage. In the setting of hydrogen streams in the soil there is the intense recovering mode forming, and the soil acidity grows noteworthily. In the water-formed depressions without the hydrogen the $\mathrm{pH}$ readings can decrease slightly and only in the upper horizon. In the hydrogen depressions soil the carbonate neoformations disappear, and the profile becomes totally washed from carbonates. And in the soil with no hydrogen fluids the carbonate neoformations and the carbonate horizon (its depth depends on the wetting degree) are always present.

At the humus total content increasing in the hydrogen depression soils the upper humus horizon bleaching takes place. The makeup of humus changes towards the significant fulvic acids domination unlike the overwetted chernozem with no hydrogen streams, where the short-time overwetting only leads to a slight increasing of fulvic acids but the humus on the whole stays humate.

The data of pyrophosphate-alkaline extract shows that the most mobile part of humus (fulvic acids) is greater than the content of humic acids fraction by several fold. Apparently fulvic acids are the main reason of strong acidification of the soil profile up to $\mathrm{pH} 4.1$ - 5.0, which isn't typical for the sinkholes overwetted soils under the conditions of hydrogen fluids absence.

In the elevated hydrogen streams zones there are changes at the aggregates 
structure level of the soil towards the decreasing of aggregates mechanical strenth. In depression center the aggregates have weak structural bonds; they are susceptible to mechanical stress: their mechanical strenth is twice or thrice lower than in the control sample. The contrary regularity was observed in the setting of local overwetting without the endogenous hydrogen streams: the aggregates in the center of this depression distinguish by high stability. It was thrice higher than in the control sample.

So the depression soil formed under the conditions of hydrogen fluids differ from the soil outside the depression with morphological and chemical properties, the state of the organic matter and the aggregates mechanical strenth. It is important to note that at the creating of soil recovering mode the impact of the two factors in the studied depressions-temporary local overwetting and hydrogen fluid stream-was unidirectional.

\section{Inferences}

1) In the territory of Voronezh region around the Hoper fault in the ordinary chernozem the elevated concentration of endogenous hydrogen streams up to $0.65 \%$ at a depth of $100-120 \mathrm{~cm}$ was detected. These lots are confined to the center of depression $0.4-0.6 \mathrm{~m}$ high and $20-100 \mathrm{~m}$ in diameter.

2) The soils under the conditions of hydrogen fluids (in the depressions center) are distinct in their morphological properties: the upper humus horizon of the ordinary chernozem is markedly bleached comparing to the soil outside the depression (control areas). According to International color system the lightness (L) readings increase for $16 \%-30 \%$ depending on the degree of the depression development: for the center of the depression $100 \mathrm{~m}$ in diameter it's L 43 in the center and 32-in the control sample; for the depression $20 \mathrm{~m}$ in diameter it's $\mathrm{L}$ 35 in the center and L 30 outside the depression.

3) The soils in the center of the depressions I and II are characterized by very low $\mathrm{pH}$ readings in comparison with the soil outside: $\mathrm{pH} 4.5-5.0$ in the humus horizons of the bottom of the depression I and $\mathrm{pH} 6.3-7.1$ in the control sample; pH 5.3 - 5.7 in the depression II and pH 6.0 - 6.8 in the soil outside.

4) At the soil carbon under the conditions of molecular hydrogen stream the soils distinguish by elevated organic carbon content in comparison with the soil outside. Plus the difference depends on the depression size: in the center of the depression I the organic carbon content is $3.6 \%-5.4 \%$ and in the control sample it is $1.8 \%-2.4 \%$; in the depression II the organic carbon content is $2.3 \%-2.5 \%$ and in the control sample it is $2.1 \%-2.3 \%$.

5) In the setting of elevated hydrogen streams the soil fulvic acids proportion relating to humic acids fraction increases on average by a factor of three. In the big depression I in the plough horizon the difference rises up to factor of eight. By comparison, in ordinary chernozem with the absence of $\mathrm{H}_{2}$ streams the ratio of humic acids to fulvic acids is close to 1 and is $0.6-0.9$ in the upper horizons.

6) Under the conditions of endogenous hydrogen streams there are soil changes at the aggregates structural level towards the aggregates mechanical 
strength decreasing. In the center of the depression I the aggregates of $3-5 \mathrm{~mm}$ are marked by strength of $0.02 \mathrm{~N}$, and in ordinary chernozem outside the depressions $\mathrm{P}$ is $0.07-0.09 \mathrm{~N}$. For the depression II the difference is less noticeable: on the bottom of the depression the median value of $\mathrm{P}$ is $0.015 \mathrm{~N}$, and in the control area $\mathrm{P}$ is $0.05 \mathrm{~N}$. In the setting of local overwetting but without the endogenous hydrogen there is the contrary dependence of aggregates strength changing from the center towards the periphery: the aggregates in the depression center are thrice stronger than aggregates in the control sample.

7) At the absence of hydrogen fluids in the depressions soil there is the proportional connection between the aggregates strength and the humus content with a certain part of variety of data $\left(\mathrm{R}^{2}=0.47-0.48\right)$. With the endogenous factor (gaseous fluids with the predominant molecular hydrogen stream) the picture changes to the contrary: In the row from the depression center towards the periphery the humus content decreases and the aggregates strength increases, the variation of data is low $\left(\mathrm{R}^{2}=0.98\right)$.

\section{Conflicts of Interest}

The authors declare no conflicts of interest regarding the publication of this paper.

\section{References}

[1] Larin, V.N. (2005) Our Earth. Agar, Moscow, 247.

[2] Larin, N., Zgonnik, V., Rodina, S., Deville, E., Prinzhofer, A. and Larin, V.N. (2014) Natural Molecular Hydrogen Seepage Associated with Surficial, Rounded Depressions on the European Craton in Russia. Natural Resources Research, 1-15.

[3] Sukhanova, N.I., Trofimov, S.Y., Polyanskaya, L.M., Larin, N.V. and Larin, V.N. (2013) Changes in the Humus Status and the Structure of the Microbial Biomass. Eurasian Soil Science, 46, 135-144. https://doi.org/10.1134/S1064229313020142

[4] Syvorotkin, V.L. (2002) Deep Degassing of the Soil and Global Catastrophes. OOO Geoinformcentr, Moscow, 250.

[5] Kanivets, V.I. (1970) Interaction between Hydrogen, Methane and Hydrogen Sulphide and Soil Mineral Part. Pochvovedenie [Soil Science], No. 5, $52-59$ (In Russian)

[6] Shestopalov, V.M. and Makarenko, A.N. (2013) Surface and Presurface Display of Abnormal Outgassing. Geologicheskiy zhurnal [Geology Magazine], No. 3, 7-25. (In Russian)

[7] Karpachevskiy, L.O. and Zubkova, T.A. (2010) Ecological Functions of the Soils in the Agrosphere. Soil Science, 11, 55-59. (In Russian)

[8] Zaydelman, F.R. (2004) Gley Formation. Its Visual and Analytical Diagnostics. Pochvovedenie [Soil Science], No. 4, 389-398. (In Russain)

[9] Zaydelman, F.R. and Davydova, I.Y. (1989) The Reason of Chernozem Chemical and Physical Properties Degradation at Irrigation with Fresh Water. Pochvovedenie [Soil Science], No. 11, 101-108. (In Russian)

[10] Samoylova, E.M. (1981) Meadow Soils of the Forest-Steppe. Moscow University Publishing House, 283. 
[11] Akhtyrtsev, A.B. and Samoylova, E.M. (1983) The Hydromorphism Influence on the Dispensation, Accumulation and Humus Content in the Forest-Steppe Soils, Vestnik Moskovskogo Universiteta [Moscow University Reporter], Series 17, Soil Science, 3-10. (In Russian)

[12] Orlov, D.S. and Grishina, L.A. (1981) Workshop on the Chemistry of Humus. MSU (Moscow State University), Moscow, $271 \mathrm{p}$.

[13] Orlov, D.S. (1990) Soil Humic Acids and General Theory of Humification. University Publishing House, Moscow, 323.

[14] Orlov, D.S., Biryukova, O.N. and Sukhanova, N.I. (1996) Soil Organic Matter of Russian Federation. Nauka, Moscow, 254.

[15] Zubkova, T.A. and Karpachevskiy, L.O. (2001) Matrix Organization of Soil. Rusaki, Moscow, 296.

[16] Zubkova, T.A. and Sukhanova, N.I. (2009) The Mechanical Strength of the Aggregates in Ordinary Chernozem of Deposits Having a Different Age. Vestnik BGSHA im. V.P.Filippova [The Buryat State Academy of Agriculture Reporter], 28-33. (In Russian)

[17] Zubkova, T.A. and Sukhanova, N.I. (2018) Particularities of Soil Aggregates under the Conditions of Endogenous Hydrogen Seepage. Prostranstvo I vremya [Space and time], No. 1-2, 181-192. (In Russian)

[18] Bezuglova, O.S. (1978) Content of Chernozem and Chestnut Soil Humus in Rostov Region. Pochvovedenie [Soil Sience], No. 12, 15-18. (In Russian)

[19] Bezuglova, O.S. and Nazarenko, O.G. (1998) Genesis and Properties of Molten Soils in Pre-Caucasian Region. Pochvovedenie [Soil Science], No. 12, 1423-1430. (In Russian)

[20] Levshunova, S.P. (1994) Hydrogen and Its Biogeochemical Role in Hydrocarbon Gases Formation in Earth Crust Sedimentaries. Extended Abstract of Doctoral Thesis in Geological and Mineralogical Sciences. Moscow. 